\title{
Historein
}

Vol 14, No 1 (2014)

On the Edge of History and Philosophy

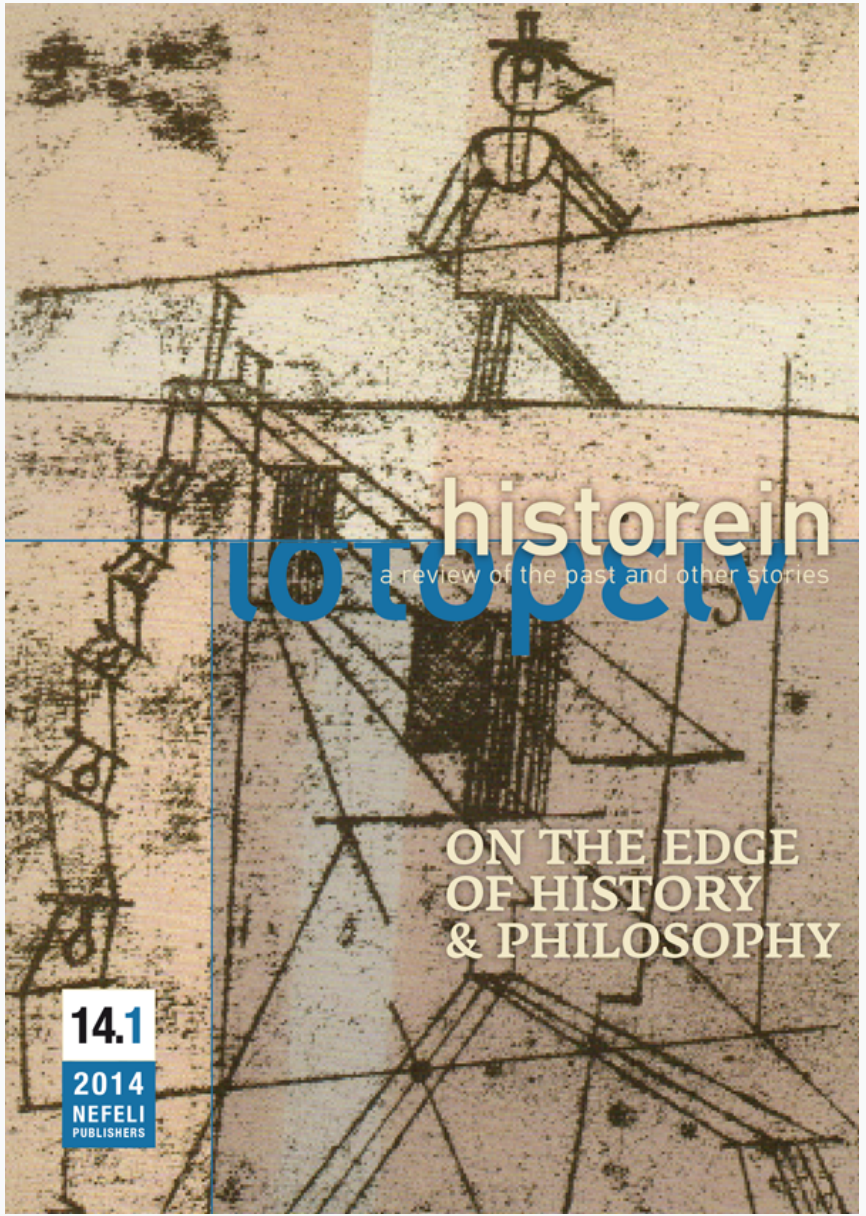

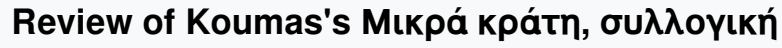

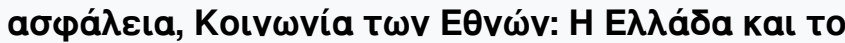

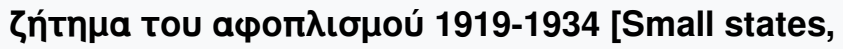
collective security, League of Nations: Greece and the disarmament question, 1919-1934]

Sotiris Rizas

doi: $10.12681 /$ historein.248

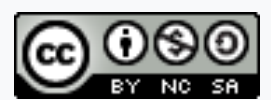

This work is licensed under a Creative Commons Attribution-NonCommercialShareAlike 4.0.

To cite this article:

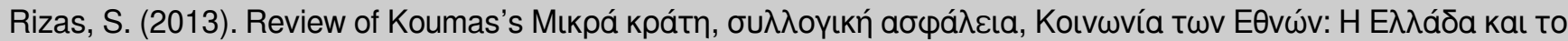

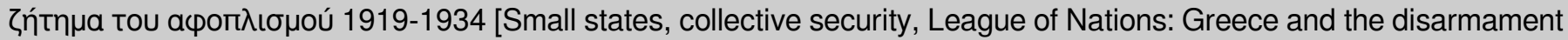
question, 1919-1934]. Historein, 14(1), 133-135. https://doi.org/10.12681/historein.248 
On "negative capability", see Robert Kaufman, "Negatively capable dialectics: Keats, Vendler, Adorno, and the theory of the avant-garde", Critical Inquiry 27/2 (2001): 354-384. For a positive evaluation of the internal contradictions of Marxism, see Alvin W. Gouldner, The Two Marxisms: Contradictions and Anomalies in the Development of Theory, London, Macmillan, 1980 [especially Appendix 3 on social "contradictions", 168-173].

\section{Manolis Koumas}

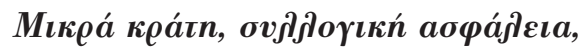

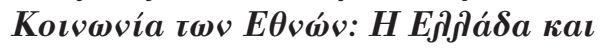

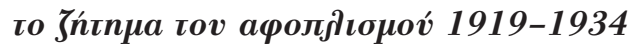

[Small states, collective security, League of Nations: Greece and the disarmament question, 1919-1934]

Nicosia: University of Cyprus

Publications, 2012, 336 pp.

\section{Sotiris Rizas}

Academy of Athens

Disarmament within the framework of the League of Nations originated from the perception of the first world war as a byproduct of the massive armaments undertaken by the Great Powers prior to its outbreak in the summer of 1914. The negotiation on disarmament was also linked to another aspect of the league's mission, the construction of a collective security framework which would supplant the traditional balance of power politics and calculations.

Manolis Koumas' book on Greece's policy towards the League of Nations' negotiations on disarmament in the interwar years is an original and interesting work covering a topic that has escaped the attention of Greek historiography. It is a well-researched book, with the author having consulted a wide array of unpublished and published archival sources Greek, British, French and American - and, simultaneously, having acquainted himself with the international literature on the subject.

It is true, and Koumas does not pretend otherwise, that this issue was not necessarily central to the formulation of Greek foreign policy after the Lausanne treaty. Very early on, after the brief occupation of Corfu by the Ital- 
ians in 1923, Athens was disillusioned with the league's ability or willingness to impose a sort of conformity to international law when this was breached by a Great Power. Greece had to employ traditional balance-of-power policies, either in the regional or European context, so that it could secure a measure of security and territorial integrity, which was Athens' predominant goal after the defeat in Asia Minor in 1922. This policy, followed in a somewhat irregular manner by Greek governments, from 1923 to 1928, with the exception of the Pangalos administration, was perfected by Venizelos in 1928-30. Realpolitik, not ideology, in which Athens calculated its interest alone and refrained from binding relationships, was the cornerstone of this policy. Venizelos succeeded in balancing the power of Yugoslavia, Mussolini's Italy and, simultaneously, normalising Greece's relations with Turkey. Still, Athens could not remain indifferent to the league's disarmament process. Absence itself would be tantamount to isolation. Moreover, as Koumas clearly points out, Greece, being in a dire financial situation as a result of the need to rehabilitate Asia Minor refugees, could not disregard a possible settlement that would alleviate the armaments burden. Furthermore, Greek policy always had to consider the revisionist aspirations of Bulgaria, which sought to secure an outlet to the Aegean. Last but not least, a nightmare haunted Greek policymakers in the form of a Yugoslav-Bulgarian rapprochement that would make the geopolitical pressure from the north unbearable. A collective security arrangement and disarmament was one way of neutralising this scenario.

The negotiations, which lasted from 1919 to 1934, were marked by the differing policy perceptions of Britain and France, the two main protagonists in the process. The former tended to perceive disarmament as a requirement for security while the latter's strategic think- ing, conversely, tended to favour the establishment of a collective security framework that would be complemented by disarmament. In the French concept, the league had to define what constituted aggression, determine the measures that would be employed to counter it and, then, impose limits on various categories of armaments.

Koumas makes plain that, in this context of Anglo-French differences, Greek policymakers felt that they had a clear interest in siding with the French proposals: the establishment of a collective security framework coupled with disarmament seemed to offer comprehensive cover for Greece's security problems, although the image of an unreliable League of Nations always loomed large in the minds of Greek officials. Apart from a few occasions when it sided with Britain, Athens retained this line of support for the French logic of disarmament as a corollary to a collective security framework. Its aberrations were not based necessarily on the intrinsic value of British proposals but on the need of a small coastal state not to alienate the preponderant naval power in the Mediterranean.

The negotiations took a turn for the worse, in fact they entered their terminal phase, in 1933-34. Hitler's rise to power and the inability of war-weary and crisis-burdened Britain and France to reach a common position led the process to an inescapable end, without an agreement in place. Greece had already reorientated its policy of noncommitment to alliances towards the conclusion of a Balkan pact, along with Yugoslavia, Romania and Turkey, in an effort to counter Bulgarian revisionism. This pact tied Greece to the wider nexus of France's European alliances, to the consternation of Venizelos, now in opposition, who opposed it bitterly. Koumas rightly argues that the change in Greek policy was not dictated 
by the failure of the negotiations on disarmament but by Greek apprehension, which was not necessarily founded on hard facts, about a potential Yugoslav-Bulgarian rapprochement. Still, there was an additional factor that pushed the anti-Venizelist government towards the conclusion of the pact - the changing dynamics of the national schism. Since 1922, Venizelos operated on the assumption that the end of the Megali Idea (Great Idea) as a policy permitted Greece to pursue a policy of noncommitment to alliances. In the mid-1930s, he was convinced that this policy was both desirable and feasible, despite the worsening international situation and the possibility of the re-emergence of blocs. His opponents, who won the March 1933 election, operated on assumptions that derived their validity from the first world war: Greece would not be able to follow a policy that contradicted the policy preferences of the dominant Mediterranean naval power. King Constantine's failure in May 1917 to continue a policy of Greek neutrality in the face of British and French opposition loomed large in anti-Venizelist memory and facilitated the undertaking of a policy of commitment to the Balkan pact. Venizelos' opposition to its conclusion served as a factor that crystallised these diverging assumptions and connected this disagreement over foreign policy to internal political dynamics.

All in all, it can be said that Greek foreign policy was not determined exclusively from the "forces profondes" or the ideological preferences of distinguished politicians, diplomats and military men who were in positions of influence.

Missing from Koumas' analysis of the overall framework of Greek foreign policy in the concluding chapter of his otherwise interesting and important book is the domestic political factor, which would permits us to fully grasp Greek policymaking.

\section{O.V. Sokolovskaia}

Grecheskaia koroleva Ol'ga

Konstantinovna - Pod molotom sud'by

\section{[The Greek queen Olga Konstantinovna: under the hammer of fate]}

\section{Moscow: Institute of Slavic Studies, 2011. 212 pp.}

\section{Lucien J. Frary}

Rider University, USA

The reign of Queen Olga Konstantinovna of Greece (1867-1913) represents a landmark in the history of Russian-Greek relations. The founder of hospitals and schools, the patroness of prison reform and social welfare, Queen Olga was a resilient woman who made a strong impression on her people. A zealous letter writer, Olga bequeathed scholars with an abundance of materials that illuminate her private and public life during one of the most turbulent 50 years in European history. Disdainful of parliamentary politics as "filthy squabbling", her adept manoeuvring through the web of European dynastic relations brought benefits to her native and adopted homelands, and her integrity proved inspirational, especially during wartime. A genuinely popular figure (above all among soldiers and sailors), historians have neglected her story until now. ${ }^{1}$

O.V. Sokolovskaia, a doctor of history and member of the Institute of Slavic Studies in the Russian Academy of Sciences, has synthesised hundreds of letters from Olga's personal collection in the State Archive of the Russian Federation (GARF) into a sympathetic portrait of the queen and her age. Consisting of a prologue, ten short chapters, and an epilogue, 